\title{
ANALYSIS OF BACTERIA Escherichia coli, Salmonella sp AND Shigella sp ON BLACK STICKY RICE ICE IN MALANG
}

\author{
Alvina Via Denita, Ainur Rofieq ${ }^{*}$, H. Husamah, Abdulkadir Rahardjanto \\ Jurusan Pendidikan Biologi, Fakultas Keguruan dan Ilmu Pendidikan, \\ Universitas Muhammadiyah Malang \\ Jalan Raya Tlogomas No.246, Kota Malang, Prov.Jawa Timur, Indonesia \\ *ainurrofieq@yahoo.co.id
}

Doi: https://doi.org/10.31943/mangiferaedu.v6i2.129

Received: October 06, 2021 Accepted: January 28, 2022 Published: January 31, 2022 Citation: Denita, V. D., Rofieq, A., Husamah, H., \& Rahardjanto, A. (2022). Analysis of Bacteria Escherchia coli, Salmonella sp and Shigella sp on Black Sticky Rice Ice in Malang. Jurnal Mangifera Edu, 6(2), 169-181.

\begin{abstract}
Black sticky rice ice is a traditional drink that is in great demand by the public ana has the potential as a source of disease transmission is in the process of processing noi using proper hygiene sanitation. The purpose of this research is to determine the content oj Escherichia coli, Salmonella sp., and Shigella sp. in black sticky rice ice. The research was conducted by planting Escherichia coli on EMBA and planting Salmonella sp., and Shigella sp. on SSA. The technique used is the spread method. The results of this study indicate that samples 1, 2, 5 and, 6 contain Escherichia coli exceeding the threshold. Samples 1, 5 and, 6 contained Salmonella sp., and Shigella sp. exceed the provisions. Microbiologica requirements of drinks based on PerBPOM RI No. 13 of 2019 is the maximum totai Escherichia coli, which is $<3$ colonies $/ \mathrm{ml}$ and 0 colonies/25ml (negative) for Salmonella sp., and Shigella sp. So, it can be concluded that 4 out of 6 samples of black sticky rice ice in Malang City do not meet the criteria for a drink that is fit for consumption based on PerBPOM RI No. 13 of 2019.
\end{abstract}

Keywords: Escherichia coli, black sticky rice ice, Salmonella sp., Shigella sp.

\section{ABSTRAK}

Es tape ketan hitam merupakan minuman tradisional yang sedang diminati oleh masyarakat. Es tape ketan hitam berpotensi sebagai sumber penularan penyakit jika dalam proses pengolahan, penyimpanan, penyajiannya tidak memperhatikan higiene dan sanitasi yang benar. Penelitian ini bertujuan untuk mengetahui kandungan bakteri Escherichia coli, Salmonella sp., dan Shigella sp. pada es tape ketan hitam. Penelitian dilakukan dengan melakukan penanaman bakteri Escherichia coli pada media EMBA dan penanaman bakteri Salmonella sp., dan Shigella sp. pada media SSA. Teknik yang digunakan berupa teknik spread plate atau metode sebar. Hasil penelitian ini menunjukkan bahwa pada sampel 1, 2, 5 dan 6 mengandung Escherichia coli melebihi ambang batas. Kemudian sampel 1, 5 dan 6 mengandung Salmonella sp., dan Shigella sp. melebihi ketentuan. Persyaratan Mikrobiologis minuman jajanan berdasarkan PerBPOM RI No. 13 tahun 2019 adalah maksimum total bakteri Escherichia coli yaitu $<3$ koloni/ml dan 0 koloni/25ml (negatif) untuk Salmonella sp., dan Shigella sp. Sehingga dapat disimpulkan 
bahwa 4 dari 6 sampel es tape ketan hitam di Kota Malang tidak memenuhi kriteria minuman layak konsumsi berdasarkan berdasarkan PerBPOM RI No. 13 tahun 2019.

Kata Kunci: Escherichia coli, Es tape ketan hitam, Salmonella sp., Shigella sp.

\section{PENDAHULUAN}

Kesehatan merupakan hal yang mahal dan hampir setiap orang rela mengeluarkan lebih banyak uang untuk mendapatkan kesehatan dan pemulihan. Salah satu faktor yang mempengaruhi kesehatan manusia berasal dari makanan dan minuman yang mereka konsumsi. Makanan dan minuman yang baik untuk dikonsumsi adalah makanan yang sehat, bergizi, dan bebas dari kontaminasi mikroorganisme dan bahan kimia berbahaya. Menurut Undang-Undang RI No. 7 Tahun 1996, Keamanan pangan adalah upaya untuk mencegah kemungkinan kontaminasi makanan oleh organisme, bahan kimia, dan benda lain yang dapat mengganggu dan membahayakan kesehatan manusia.

Salah satu penyakit akibat kelalaian manusia dalam menjaga sanitasi makanan dan minuman yang dikonsumsi adalah diare. Penyebab diare yang paling umum adalah diare infeksius, yang disebabkan oleh virus, bakteri, dan parasit. Menurut Musyayadah \& Adiningsih (2019). Penyebab utama dari penyakit diare sendiri adalah adanya kontaminasi biologis atau kontaminasi faktor patogen termasuk virus, bakteri, dan parasit pada makanan dan minuman yang kita konsumsi. Rahayuningsih et al., (2017) menegaskan bahwa penyebab utama penyakit diare adalah infeksi bakteri patogen yang masuk ke dalam tubuh manusia. Pendapat Puspitasari \& Mukono (2013) mengatakan bahwa penyakit diare adalah penyakit yang dapat disebabkan oleh bakteri yang bertransmisi melalui air seperti Escherichia coli, Salmonella sp. (non thypoid), dan Shigella sp.

Bakteri Escherichia coli merupakan bakteri fekal yang keberadaannya dijadikan indikator pencemaran makanan maupun minuman. Hal tersebut sejalan dengan pendapat Yunus et al., (2010) bahwa Escherichia coli juga menjadi salah satu indikator terjadinya pencemaran makanan yang dapat menyebabkan penyakit akibat makanan (food borne diseases). Menurut Ningrum \& Sulistyorini (2019), juga mengatakan bahwa bakteri Escherichia coli di dalam air erat kaitannya dengan adanya bibit penyakit. Bakteri Salmonella sp. umumnya ditularkan ke manusia melalui konsumsi minuman atau makanan yang terkontaminasi. Gejala infeksi Salmonella sp. biasanya muncul 12-72 jam setelah infeksi dan meliputi demam, sakit perut, diare, mual dan kadang muntah (Fhitryani et al., 2017). Bakteri Shigella sp. merupakan jenis bakteri penyebab diare akut. Menurut Aini (2018), diare yang dikeluarkan akibat Shigella sp. dapat bercampur dengan lendir dan darah. 
Penyakit diare sangat erat kaitannya dengan kebersihan dan sanitasi makanan. Mutu higienis makanan jajanan yang rendah disebabkan perilaku orang yang mengolahnya, umumnya tidak memenuhi syarat kesehatan, kebersihan lingkungan, ketersediaan sarana penunjang, dan kondisi bahan baku. Buruknya proses pengolahan makanan maupun minuman dipengaruhi oleh faktor lingkungan dan juga faktor perilaku, yaitu kebersihan dalam proses pengolahannya merupakan pemicu utama penyakit diare (Riyanto \& Abdillah, 2012).

Saat ini di Indonesia budaya jajan menjadi bagian dari keseharian hampir semua kelompok usia maupun kelas sosial. Selain praktis dan mudah didapat, makanan jenis ini umumya memiliki harga yang terjangkau, memiliki rasa yang lezat serta disajikan dengan cepat. Semakin berkembangnya zaman, semakin beragam pula jenis minuman yang dijajakan oleh pedagang baik di perkotaan maupun di pedesaan. Kendati demikian minuman jajanan tersebut juga berisiko terhadap kesehatan. Hal ini disebabkan oleh proses pembuatan yang sering tidak higienis (Hidayah et al., 2017). Tak hanya itu minuman tersebut seringkali dijajakan di pinggir jalan atau tempat keramaian yang potensi cemaran biologisnya juga tinggi.

Salah satu minuman jajanan yang saat ini sedang ramai peminatnya di Kota Malang adalah es tape ketan hitam. Terjadinya kontaminasi silang dengan mikroorganisme patogen rentan terjadi pada makanan dan minuman yang dijual di pinggir jalan, seperti pada es tape ketan hitam (Abduh \& Salim, 2019; Audia \& Handayani, 2017). Es tape yang terkontaminasi tak jarang membuat keracunan, bahkan menyebabkan konsumen menderita sakit dan meninggal (Gunawan, 2018; Supriadi, 2018). Dengan kondisi kota Malang yang panas, es tape ketan hitam merupakan pilihan tepat untuk dijadikan pemuas dahaga. Es tape ketan hitam sendiri merupakan es yang terbuat dari santan kelapa, tape ketan hitam, sirup serta terdapat tambahan roti tawar di atasnya yang kemudian didinginkan di freezer (lemari es) tanpa dicampur dengan es balok/es batangan. Tempat penjualan es tape ketan hitam berada di pinggiran jalan raya dan daerah keramaian seperti lingkungan pasar maupun di sekitar sekolah yang mana pada tempat tersebut sangat rawan sekali terjadinya kontaminasi mikroba apabila dalam penyajian dan pengolahan tidak dilakukan secara higienis. Proses pengolahannya es tape ketan hitam masih dilakukan secara tradisional sehingga ke higienisannya belum terjamin dan kemungkinan terkontaminasi sangat besar. Oleh karena itu, penelitian ini bertujuan untuk mengetahui kandungan bakteri Escherichia coli, Salmonella sp., dan Shigella sp. pada es tape ketan hitam di Kota Malang. Hasil penelitian 
ini dapat memberikan gambaran dan pengetahuan kepada masyarakat untuk lebih berhatihati dalam memilih makanan maupun minuman pinggir jalan yang akan dikonsumsi.

\section{METODOLOGI PENELITIAN}

Penelitian yang akan dilakukan yaitu menganalisis kandungan bakteri Escherichia coli, Salmonella sp., Shigella sp. dan menghubungkannya dengan tingkat perilaku kebersihan pedagang es tape ketan hitam di Kota Malang. Penelitian ini dilaksanakan pada Bulan Juli 2021 di Kota Malang dan Laboratorium Biomedik Fakultas Kedokteran Universitas Muhammadiyah Malang.

Populasi dalam penelitian ini adalah seluruh pedagang es tape ketan hitam yang berada di Kota Malang. Sampel yang digunakan dalam penelitian ini dipilih dengan menggunakan Teknik Cluster Random Sampling. Kota Malang merupakan kota di Jawa Timur yang terdiri atas lima kecamatan. Dari populasi seluruh pedagang es tape ketan hitam di Kota Malang dipilih tiga kecamatan yang berbeda dan pada setiap kecamatan dipilih dua pedagang es tape ketan hitam. Pemilihan tiga kecamatan tersebut berdasarkan sebaran penjual es tape keta hitam dominan di tiga kecamatan tersebut. Selanjutnya dari masing-masing es tape ketan hitam yang telah didapatkan tersebut diambil untuk dijadikan sampel perlakuan. Kemudian dari setiap es tape ketan hitam diberi dua kali pemeriksaan yaitu pemeriksaan kandungan Escherichia coli, dan pemeriksaan kandungan Salmonella sp., dan Shigella sp.

Media SSA (Salmonella Shigella Agar) merupakan media selektif yang dapat menumbuhkan bakteri Salmonella dan Shigella. Sedangkan Media EMBA merupakan media selektif yang dapat menumbuhan bakteri Escherichia coli. Adapun tahapan yang perlu dilakukan untuk analisis kandungan bakteri Salmonella sp. pada media SSA dan kandungan bakteri Escherichia coli pada media EMBA dengan teknik Spread Plate (metode sebar).

a. Langkah-langkah Pembuatan Media Agar

Media SSA sebanyak 18,9 g dicairkan dengan aquades $330 \mathrm{ml}$ dan media EMBA sebanyak 11,8 g dicairkan dengan aquades $330 \mathrm{ml}$. Kemudian diaduk sampai larut dan dipanaskan hingga mendidih. Setelah mendidih lalu disterilkan dan dituangkan ke cawan petri hingga media padat.

\section{b. Langkah-langkah Analisis Kandungan Bakteri}

Analisis kandungan bakteri diawali dengan menyiapkan alat dan bahan dengan disterilkan terlebih dahulu, kemudian menimbang sampel sebanyak 1 gr. Menghomogenkan sampel dengan larutan aquades sebanyak $9 \mathrm{ml}$ dan dihomogenkan menggunakan vortex, memasukkan kapas lidi pada sampel, kemudian menyebarkan kapas lidi pada media SSA 
yang telah padat dan juga menyebarkan sampel pada media EMBA dengan kapaslidi yang lainnya. Teknik yang digunakan merupakan metode Spread plate di dalam alat inokulasi. Cawan petri kemudian ditutup menggunakan plastic wrap. Dilanjutkan memasukkan cawan petri ke dalam inkubator dengan suhu $37^{\circ} \mathrm{C}$ selama $24 \mathrm{jam}$. Langkah akhir adalah mengamati adanya cemaran bakteri pada media masing-masing.

Pada penelitian ini data ditabulasikan dengan menganalisis data secara deskriptif dengan melakukan pemeriksaan kandungan bakteri Escherichia coli, bakteri Salmonella sp. dan bakteri Shigella sp. pada permukaan medium agar SSA dan EMBA. Hasil yang didapatkan akan dibandingkan persyaratan mikrobiologis minuman jajanan berdasarkan PerBPOM RI No. 13 tahun 2019 adalah maksimum total bakteri Escherichia coli yaitu < 3 koloni/ml dan 0 koloni/25ml (negatif) untuk Salmonella sp., dan Shigella sp.

\section{HASIL DAN PEMBAHASAN}

Penelitian dilaksanakan pada tanggal 22-24 Juli 2021 di Laboratorium Biomedik Universitas Muhammadiyah Malang, hasil penelitian menguji kandungan Escherichia coli, Salmonella sp., dan Shigella sp. pada es tape ketan hitam.

Hasil penelitian pemeriksaan kandungan bakteri Escherichia coli pada es tape ketan hitam di Kota Malang yang telah dilakukan didapatkan hasil pada Tabel 1.

Tabel 1. Kandungan Bakteri Escherichia coli pada es tape ketan hitam pada enam pedagang di Kota Malang

\begin{tabular}{|c|c|c|c|c|c|c|}
\hline \multirow{2}{*}{ Sampel } & \multicolumn{3}{|c|}{ Total Escherichia coli $(\mathbf{c f u} / \mathrm{ml})$} & \multirow{2}{*}{ Rerata } & \multirow{2}{*}{$\begin{array}{l}\text { Standar } \\
\text { (CFU/ml) }\end{array}$} & \multirow{2}{*}{ Keterangan } \\
\hline & $\begin{array}{c}\text { Ulangan } 1 \\
\text { Hasil }\end{array}$ & $\begin{array}{c}\text { Ulangan } 2 \\
\text { Hasil }\end{array}$ & $\begin{array}{c}\text { Ulangan } 3 \\
\text { Hasil }\end{array}$ & & & \\
\hline 1 & $3 \times 10^{3}$ & $3 \times 10^{3}$ & $3 \times 10^{3}$ & $3 \times 10^{3}$ & $<3$ & $\begin{array}{l}\text { Tidak Meтеnuhi } \\
\text { Standar BРОM }\end{array}$ \\
\hline 2 & $3 \times 10^{3}$ & $3 \times 10^{3}$ & $3 \times 10^{3}$ & $3 \times 10^{3}$ & $<3$ & $\begin{array}{l}\text { Tidak Memenuhi } \\
\text { Standar BРОM }\end{array}$ \\
\hline 3 & 0 & 0 & 0 & 0 & $<3$ & $\begin{array}{c}\text { Memenuhi Standar } \\
\text { BPOM }\end{array}$ \\
\hline 4 & 0 & 0 & 0 & 0 & $<3$ & $\begin{array}{c}\text { Memenuhi Standar } \\
\text { ВРOM }\end{array}$ \\
\hline 5 & $28 \times 10^{3}$ & $19 \times 10^{3}$ & $22 \times 10^{3}$ & $23 \times 10^{3}$ & $<3$ & $\begin{array}{c}\text { Tidak Meтепиhi } \\
\text { Standar BРОМ }\end{array}$ \\
\hline 6 & $18 \times 10^{3}$ & $19 \times 10^{3}$ & $17 \times 10^{3}$ & $18 \times 10^{3}$ & $<3$ & $\begin{array}{l}\text { Tidak Memenuhi } \\
\text { Standar BPOM }\end{array}$ \\
\hline
\end{tabular}

Keterangan: berdasarkan PerBPOM RI No.13 Tahun 2019

Data Tabel 1. menunjukkan bahwa terdapat kandungan bakteri Escherichia coli pada beberapa sampel es tape ketan hitam di Kota Malang. Sampel dari pedagang 1, 2, 5 dan 6 menunjukkan adanya cemaran bakteri Escherichia coli. Hal tersebut dibuktikan dengan hasil rerata kandungan bakteri Escherichia coli pada sampel pedagang satu sebesar $3 \times 10^{3}$, sampel 
pedagang dua sebesar $3 \times 10^{3}$, sampel pedagang lima sebesar $23 \times 10^{3}$, dan sampel pedagang enam sebesar $18 \times 10^{3}$. Merujuk pada kriteria mikrobiologi dalam minuman jajanan pada PerBPOM RI No. 13 tahun 2019 bahwa standar untuk jumlah maksimum total bakteri Escherichia coli yaitu < 3 koloni/ml, sehingga dapat dikatakan bahwa sampel 1,2,5, dan 6 tidak memenuhi syarat atau standar BPOM. Terdeteksinya Escherichia coli pada sampel tersebut merupakan indikator tercemarnya air atau makanan karena keberadaan bakteri Escherichia coli dalam sumber air atau makanan merupakan indikasi terjadinya kontaminasi tinja manusia (Putri et al., 2015).

Penggunaan air yang buruk dapat menjadi faktor utama terkontaminasinya minuman oleh bakteri Escherichia coli. Apabila kualitas air tidak memenuhi syarat persyaratan kesehatan dapat menjadi media penularan penyakit (Yunus et al., 2015). Selain itu, menurut (Afandi, 2013) adanya Escherichia coli juga menandakan buruknya proses sanitasi karena Escherichia coli bisa berpindah dengan kegiatan tangan ke mulut atau dengan pemindahan pasif lewat makanan, air, susu dan produk-produk lainnya. Tak hanya itu untuk meminimalkan biaya produksi sebagian pedagang membuat es batu sendiri dengan menggunakan air yang tidak layak sebagai bahan baku es batu. Meilisnawaty et al (2015) juga mengatakan bahwa es batu yang terbuat dari air mentah dapat mengandung bakteri Escherichia coli.

Keberadaan Escherichia coli pada pangan dapat menimbulkan beragam penyakit seperti diare. Afandi (2013) menyatakan bahwa Escherichia coli yang terdapat pada makanan atau minuman yang masuk kedalam tubuh manusia dapat menyebabkan gejala seperti kholera, disentri, gastroenteritis, diare dan berbagai penyakit saluran pencernaan lainnya. Escherichia coli yang masuk ke dalam usus juga kemudian dapat menghasilkan toksin sehingga menyebabkan penyakit pada saluran pencernaan (Zein, 2004). Beberapa penelitian, menunjukkan bahwa beberapa strain Escherichia coli juga dapat menyebabkan wabah diare atau muntaber, terutama pada anak-anak.

Berbeda pada sampel pedagang 3 dan 4 menunjukkan tidak ditemukan cemaran bakteri Escherichia coli. Hal tersebut dibuktikan dengan hasil $0 \mathrm{cfu} / \mathrm{ml}$ untuk kandungan bakteri Escherichia coli sehingga kedua sampel tersebut layak untuk dikonsumsi karena sesuai dengan kriteria mikrobiologi dalam minuman jajanan berdasarkan PerBPOM RI No.13 tahun 2019. Jika makanan dan minuman tersebut diolah secara higienis, mungkin bakteri di dalamnya masih memiliki batas toleransi untuk dikonsumsi terutama bakteri patogen penyebab penyakit. 
Hasil penelitian pemeriksaan kandungan bakteri Salmonella sp. pada es tape ketan hitam di Kota Malang yang telah dilakukan didapatkan hasil pada Tabel 2.

Tabel 2. Kandungan Bakteri Salmonella sp. pada es tape ketan hitam pada enam pedagang di Kota Malang

\begin{tabular}{|c|c|c|c|c|c|c|}
\hline \multirow{3}{*}{ Sampel } & \multicolumn{3}{|c|}{ Total Salmonella sp. (cfu/25ml) } & \multirow{3}{*}{ Rerata } & \multirow{3}{*}{$\begin{array}{c}\text { SNI } \\
(\mathrm{cfu} / 25 \mathrm{ml})\end{array}$} & \multirow{3}{*}{ Keterangan } \\
\hline & Ulangan 1 & Ulangan 2 & Ulangan 3 & & & \\
\hline & Hasil & Hasil & Hasil & & & \\
\hline 1 & $10^{3}$ & $3 \times 10^{3}$ & $2 \times 10^{3}$ & $3 \times 10^{3}$ & negatif & Tidak Memenuhi SNI \\
\hline 2 & 0 & 0 & 0 & 0 & negatif & Memenuhi SNI \\
\hline 3 & 0 & 0 & 0 & 0 & negatif & Memenuhi SNI \\
\hline 4 & 0 & 0 & 0 & 0 & negatif & Memenuhi SNI \\
\hline 5 & $13 \times 10^{3}$ & $15 \times 10^{3}$ & $11 \times 10^{3}$ & $13 \times 10$ & negatif & Tidak Memenuhi SNI \\
\hline 6 & $14 \times 10^{3}$ & $11 \times 10^{3}$ & $20 \times 10^{3}$ & $18 \times 10$ & negatif & Tidak Memenuhi SNI \\
\hline
\end{tabular}

Keterangan: SNI yaitu berdasarkan PerBPOM RI No.13 Tahun 2019

Berdasarkan Tabel 2. dapat dilihat bahwa ditemukan kandungan bakteri Salmonella $s p$. pada sampel 1, 5, dan 6. Hal tersebut dibuktikan dengan hasil rerata kandungan bakteri pada sampel pedagang satu sebesar $3 \times 10^{3}$, sampel pedagang lima sebesar $13 \times 10^{3}$, dan sampel pedagang enam sebesar $18 \times 10^{3}$. Merujuk pada kriteria mikrobiologi dalam minuman jajanan pada PerBPOM RI No. 13 tahun 2019 bahwa SNI untuk jumlah maksimum total bakteri Salmonella sp. yaitu 0 koloni/25ml (negatif), sehingga dapat dikatakan bahwa sampel 1,5, dan 6 tidak memenuhi kriteria.

Namun pada sampel pedagang 2, 3, dan 4 menunjukkan hasil bahwa tidak ditemukannya kandungan bakteri Salmonella sp. Terbukti dari uji yang dilakukan pada sampel 2, 3, dan 4 dengan tiga kali pengulangan didapat hasil $0 \mathrm{cfu} / \mathrm{ml}$ untuk kandungan bakteri Salmonella sp. sehingga ketiga sampel tersebut layak untuk dikonsumsi karena sesuai dengan kriteria mikrobiologi dalam minuman jajanan berdasarkan PerBPOM RI No.13 tahun 2019.

Bakteri Salmonella sp. bisa terdapat di udara, air, tanah, sisa kotoran manusia maupun hewan atau makanan (Arlita et al., 2014). Salmonella sp. yang mencemari makanan dapat berkembang biak dengan cukup cepat karena didukung dengan kondisi lingkungan yang panas dan lembab sehingga menstimulir pertumbuhannya. Es tape ketan hitam yang dijual di area terbuka pada siang hari dengan kondisi panas menjadi salah satu pemicu adanya cemaran Salmonella sp. pada es tape ketan hitam yang diperdagangkan di Kota Malang.

Sumber kontaminasi makanan maupun minuman Salmonella sp. seringkali disebabkan karena kurang baiknya proses sanitasi. Menurut Mirawati et al., (2014) 
Banyaknya sampel jajanan yang terkontaminasi tidak lepas dari kondisi lingkungan tempat berdagang, kebersihan alat, wadah tempat berjualan dan higiene pedagangnya. Bakteri ini merupakan bakteri indikator pencemaran pangan, sehingga adanya bakteri ini dalam makanan dianggap membahayakan kesehatan (Arlita et al., 2014).

Konsumsi makanan atau minuman yang mengandung Salmonella $s p$. dapat menimbulkan gejala yang disebut salmonellosis. Kasus ini biasa terjadi pada konsumsi Salmonella $s p \cdot 10^{5-6} \mathrm{sel}$, namun untuk beberapa kasus salmonellosis juga terjadi pada konsumsi beberapa sel saja (Sopandi \& Wardah, 2014). Selain itu makanan yang terkontaminasi Salmonella sp. dapat menyebabkan demam tifoid bila dikonsumsi dan jumlahnya melebihi batas selain itu juga dapat menyebabkan keracunan makanan karena toksin yang dihasilkannya (Mirawati et al., 2014).

Sedikit temuan Salmonella sp. pada makanan maupun minuman sudah menandakan bahwa makanan tersebut tidak baik untuk dikonsumsi. Sebab sesuai pendapat Kumar et al., (2019) untuk menyebabkan infeksi hanya diperlukan sedikit organisme Salmonella sp. dalam usus. Sehingga menurut kriteria PerBPOM pun menyatakan bahwa kandungan Salmonella sp. pada makanan harus $0 \mathrm{cfu} / 25 \mathrm{ml}$ atau negatif. Salmonella $s p$. yang terdapat dalam makanan kemudian akan ikut terkonsumsi akan masuk ke dalam usus sehingga Salmonella $s p$. dapat menginvasi sel epitel usus. Enterotoksin yang dihasilkan oleh Salmonella sp. akan menyebabkan diare. Bila terjadi kerusakan mukosa yang menimbulkan ulkus, maka akan terjadi bloody diarrhea (Zein, 2004).

Hasil penelitian pemeriksaan kandungan bakteri Shigella sp. pada es tape ketan hitam di Kota Malang yang telah dilakukan didapatkan hasil pada Tabel 3.

Tabel 3. Kandungan Bakteri pada Shigella sp. pada es tape ketan hitam pada enam pedagang di Kota Malang

\begin{tabular}{|c|c|c|c|c|c|c|}
\hline \multirow{3}{*}{ Sampel } & \multicolumn{3}{|c|}{ Total Shigella sp. (cfu/25ml) } & \multirow{3}{*}{ Rerata } & \multirow{3}{*}{$\begin{array}{c}\text { SNI } \\
\text { (cfu/25ml) }\end{array}$} & \multirow{3}{*}{ Keterangan } \\
\hline & Ulangan 1 & Ulangan 2 & Ulangan 3 & & & \\
\hline & Hasil & Hasil & Hasil & & & \\
\hline 1 & $6 \times 10^{3}$ & $12 \times 10^{3}$ & $6 \times 10^{3}$ & $8 \times 10^{3}$ & negatif & Tidak Memenuhi SNI \\
\hline 2 & 0 & 0 & 0 & 0 & negatif & Memenuhi SNI \\
\hline 3 & 0 & 0 & 0 & 0 & negatif & Memenuhi SNI \\
\hline 4 & 0 & 0 & 0 & 0 & negatif & Memenuhi SNI \\
\hline 5 & $6 \times 10^{3}$ & $4 \times 10^{3}$ & $2 \times 10^{3}$ & $4 \times 10^{3}$ & negatif & Tidak Memenuhi SNI \\
\hline 6 & $9 \times 10^{3}$ & $45 \times 10^{3}$ & $15 \times 10^{3}$ & $23 \times 10^{3}$ & negatif & Tidak Memenuhi SNI \\
\hline
\end{tabular}

Keterangan: SNI yaitu berdasarkan PerBPOM RI No.13 Tahun 2019

Data Tabel 3. memperlihatkan bahwa ditemukan kandungan bakteri Shigella sp. pada sampel 1, 5, dan 6. Hal tersebut dibuktikan dengan hasil rerata kandungan bakteri pada 
sampel pedagang satu sebesar $8 \times 10^{3}$, sampel pedagang lima sebesar $4 \times 10^{3}$, dan sampel pedagang enam sebesar $23 \times 10^{3}$. Merujuk pada kriteria mikrobiologi dalam minuman jajanan pada PerBPOM RI No. 13 tahun 2019 bahwa SNI untuk jumlah maksimum total bakteri Shigella sp. yaitu 0 koloni/25ml (negatif), sehingga dapat dikatakan bahwa sampel 1,5, dan 6 tidak memenuhi kriteria.

Berbeda pada sampel pedagang 2, 3, dan 4 menunjukkan hasil bahwa tidak ditemukannya kandungan bakteri Shigella sp. Terbukti dari uji yang dilakukan pada sampel 2, 3 dan 4 didapat hasil $0 \mathrm{cfu} / \mathrm{ml}$ untuk kandungan bakteri Shigella sp. sehingga ketiga sampel tersebut layak untuk dikonsumsi sebab sesuai dengan kriteria mikrobiologi dalam minuman jajanan berdasarkan PerBPOM RI No.13 tahun 2019.

Keberadaan Shigella sp. pada minuman es tape ketan hitam ini berkaitan dengan juga dengan terdeteksinya Escherichia coli. Kontaminasi Shigella sp pada minuman lebih banyak berasal dari air yang digunakan pada saat proses pengolahan (Sopandi \& Wardah, 2014). Terdeteksinya Shigella sp. pada sampel 1,5 dan 6 menunjukkan bahwa kualitas air yang digunakan tidak memenuhi syarat dan tidak aman dari cemaran bakteri.

Selain itu adanya Shigella sp. pada makanan atau minuman menunjukkan buruknya sanitasi pada saat pengolahan. Menurut Setiawati et al., (2018) penjual yang masih menyajikan jajanannya dalam kondisi terbuka, jajanan terpapar langsung oleh asap kendaraan dan debu lingkungan sehingga akan mudah terkontaminasi bakteri. Bakteri ini juga dapat menyebar melalui alat pengolahan yang digunakan kurang higiene dan waktu penyimpanan yang terlalu lama (Apriani et al., 2019). Keberadaan bakteri Shigella sp. sama bahanya dengan Salmonella sp. karena kedua bakteri ini merupakan bakteri indikator keamanan pangan.

Salah satu penyakit yang disebabkan oleh bakteri ini adalah disentri. Infeksi yang disebabkan Shigella sp. biasanya terjadi melalui makanan, air yang terkontaminasi oleh bakteri tersebut. Pada penderita anak-anak atau penderita berusia lanjut, penyakit disentri dapat berlangsung lama, bahkan dapat menyebabkan kematian. Infeksi yang fatal oleh bakteri ini juga dapat mengakibatkan reaksi pada syaraf susunan pusat misalnya miningismus, koma (Ariana, 2017). Organisme Shigella sp. paling banyak ditemukan di usus dimana ketika Shigella sp. sudah berada pada usus, organisme tersebut akan diambil oleh sel epitel yang kemudian bakteri tersebut menginfeksi sel epitel usus kecil dan kolon melalui membran basolateral, yang merupakan reseptor bakteri sehingga menyebabkan penyakit diare maupun disentri (Kumar et al., 2019). 
Ketersediaan dan keamanan makanan dan minuman merupakan hak dasar manusia. "Salah satu pemenuhan kebutuhan masa depan adalah higiene dan sanitasi makanan, agar terhindar dari cemaran bakteri patogen. Makanan yang diharapkan oleh masyarakat yaitu makanan yang bersih, aman dan sehat atau bebas dari cemaran mikroba sesuai dengan standar keamanan pangan” (Hariyati et al., 2018). Salah satu kelompok masyarakat yang sering mengalami masalah akibat keracunan makanan dan minuman adalah mayarakat yang sering mengkonsumsi makanan dan minuman pinggir jalanan (Nurbiyati \& Wibowo, 2014). Pedagang makanan dan minuman pnggir jalan umumnya memakai fasilitas yang masih sederhana sehingga kurang memenuhi persyaratan hygiene-sanitasi dan akhirnya mempengaruhi kualitas bakteriologis makanan (Morestavia \& Sulistyorini, 2014).

Hygiene-sanitasi dapat dipengaruhi oleh beragam faktor. Minimal ada tiga faktor utama, yaitu "penjamah makanan/minuman", "lingkungan tempat makanan/minuman diproses", dan "fasilitas atau peralatan pengolah makanan/minumaan yang digunakan". Berdasarkan ketiga hal tersebut, faktor "penjamah makanan/minuman" dianggap atau disinyalir berperan paling penting karena ia bersifat dominan. Maksudnya adalah bahwa manusia "bersifat aktif sehingga mampu mengubah diri dan lingkungan ke arah yang lebih baik maupun sebaliknya” (Fajriansyah, 2016; Yasmin \& Madanijah, 2010).

"Dengan melihat potensi makanan jajanan yang demikian besar dan tingkat kerawanan yang cukup tinggi perlu diupayakan pengawasan kualitas pengelolaan makanan jajanan dengan memperhatikan kaidah-kaidah (kebersihan/hygiene) dan sanitasi serta persyartan kesehatan. Sekitar $80 \%$ penyakit yang tertular melalui makanan disebabkan oleh bakteri pathogen.” (Rahmayani, 2018).

\section{SIMPULAN}

Terdapat kandungan bakteri Escherichia coli, Salmonella sp., dan Shigella sp. pada 4 sampel es tape ketan hitam (67\%) yang diperdagangkan di Kota Malang dan tidak memenuhi standar kelayakan konsumsi berdasarkan PerBPOM RI No. 13 Tahun 2019. Oleh karena itu masyarakat umum diimbau untuk lebih waspada salam dalam memilih dan memilah makanan atau minuman pinggir jalan yang akan dikonsumsi agar tidak berdampak buruk bagi kesehatan. Kriteria dalam memilih makanan dan minuman pinggir jalan adalah lihatlah kehigienisan lokasi tempat mereka berjualan, lihatlah peralatan yang digunakan, amati proses mereka menyajikan dan memasak, dan sebaiknya bawa peralatan sendiri untuk menghindari pengemasan yang terkontaminasi. 


\section{DAFTAR PUSTAKA}

Abduh, M. N., \& Salim, A. (2019). Pengembangan dan kelayakan usaha "poteng" di Galesong Kabupaten Takalar Sulawesi Selatan. Jurnal Ecosystem, 19(3), 258-263.

Afandi, D. (2013). Faktor Kontaminasi Bakteri Sekolah Dasar Wilayah Kecamatan Bangkinang. Jurnal Ilmu Lingkungan, 7(1), 28-37.

Aini, F. (2018). Isolasi dan identifikasi shigela sp. penyebab diare pada balita. Bio-Site, 4(1), $1-40$.

Apriani, L., Rahmawati, R., \& Kurniatuhadi, R. (2019). Deteksi Bakteri Salmonella Dan Shigella Pada Makanan Burger Di Sungai Raya Dalam Pontianak. Jurnal Protobiont, 8(3), 53-57. https://doi.org/10.26418/protobiont.v8i3.36836

Ariana, D. (2017). Uji Antibakteri Perasan Daun Pandan Wangi (Pandanus amaryllifolius Roxb.) terhadap Shigella dysentriae. The Journal Of Muhammadiyah Medical Laboratory Technologist, 2(1), 67-72.

Arlita, Y., Rares, fredine e s, \& Soeliongan, S. (2014). Identifikasi Bakteri Escherichia Coli Dan Salmonella Sp. Pada Makanan Jajanan Bakso Tusuk Di Kota Manado. Jurnal EBiomedik, 2(1), 9-14. https://doi.org/10.35790/ebm.2.1.2014.4387

Audia, W. P., \& Handayani, M. N. (2017). Pengaruh perbedaan metode pengeringan terhadap karakteristik sensori dan kimiawi tape ketan hitam instan. Edufortech, 2(1), 59-67.

Fajriansyah, F. (2016). Hygiene dan Sanitasi Pengolahan Roti pada Pabrik Roti Paten Bakery. AcTion: Aceh Nutrition Journal, 1(2), 116-120.

Fhitryani, S., Suryanto, D., \& Karim, A. (2017). Pemeriksaan Escherichia coli, Staphylococcus aureus dan Salmonella sp. pada jamu gendong yang dijajakan di Kota Medan. Biolink (Jurnal Biologi Lingkungan, Industri, Kesehatan), 3(2), 144.

Gunawan, H. (2018). Habis makan tape ketan, 38 orang keracunan, satu meninggal. TribunNews.com. https://www.tribunnews.com/regional/2018/01/02/habis-makantape-ketan-38-orang-keracunan-satu-meninggal

Hariyati, N., Budiyanto, M. A. K. \& Husamah, H. (2018). Hubungan Higiene Sanitasi Pedagang Sosis Bakar di Car Free Day (CFD) Kota Malang terhadap Jumlah Koloni Bakteri. Jurnal Ilmu Dasar, 19(2), 71-76.

Hidayah, R., Asterina, A., \& Afriwardi, A. (2017). Hubungan tingkat pendidikan dan pengetahuan penjual es campur tentang zat pewarna berbahaya dengan kandungan rhodamin b dalam buah kolang kaling di Kota Padang. Jurnal Kesehatan Andalas, 6(2), 283. https://doi.org/10.25077/jka.v6i2.692

Kumar, V., K.Abbas, A., \& Aster, J. C. (2019). Buku Ajar Patologi Dasar Robins. Elsevier Health Science. https://www.mendeley.com/catalogue/543c724d-2cc1-3291-bb4ea0746daabdbc/ 
Meilisnawaty, D., Suryanto, D., \& Fauziah, I. (2015). Pemeriksaan Escherichia coli, Staphylococcus aureus dan Salmonella pada es jus jeruk examination. BIOLINK (Jurnal Biologi Lingkungan, Industri, Kesehatan), 2(1), 55-63.

Mirawati, M., Lestari, E., \& Djajaningrat, H. (2014). Identifikasi salmonella pada jajanan yang dijual di kantin dan luar kantin sekolah dasar. Jurnal Ilmu Dan Teknologi Kesehatan, 1(2), 141-147.

Morestavia, S. \& Sulistyorini, L. (2014). Consumer Health Complaints and Hygiene Sanitation of "Penyetan" at Arif Rachman Hakim Street Vendors in Surabaya. Jurnal Kesehatan Lingkungan, 7(2), 83-89

Musyayadah, \& Adiningsih, S. (2019). Hubungan ketahanan pangan keluarga dan frekuensi diare dengan stunting pada balita di kampung surabaya the relationship between family food security and the frequency of diarrhea among stunted toddlers in kampung surabaya. Amerta Nutrition, 3(4), 257-262. https://doi.org/10.2473/amnt.v3i4.2019.

Ningrum, L. F., \& Sulistyorini, L. (2019). Kondisi sanitasi peralatan dan higiene bahan minuman terhadap keberadaan bakteri eschericia coli pada es teh di warung kelurahan mulyorejo, surabaya. The Indonesian Journal of Public Health, 14(2), 186. https://doi.org/10.20473/ijph.v14i2.2019.187-199

Nurbiyati, T. \& Wibowo, A. H. (2014). Pentingnya memilih jajanan sehat demi kesehatan anak. Jurnal Inovasi dan Kewirausahaan, 3(3), 192-196.

Puspitasari, S., \& Mukono, J. (2013). Hubungan kualitas bakteriologis air sumur dan perilaku sehat dengan kejadian waterborne disease di desa tambak sumur, kecamatan waru, kabupaten sidoarjo. Jurnal Kesehatan Lingkungan, 7(1), 76-82.

Putri, R. K., Nurjazuli, \& Hanani, D. yusniar. (2015). Hubungan Higiene Dan Sanitasi Makanan Dengan Kontaminasi Bakteri Escherichia Coli Dalam Makanan Di Warung Makan Sekitar Terminal Borobudur, Magelang. Jurnal Kesehatan Masyarakat, 3(1), 549-558. http://ejournal-s1.undip.ac.id/index.php/jkm

Rahayuningsih, D., Martini, Purwantisari, S., \& Hestiningsih, R. (2017). Hubungan higiene penjamah dengan kualitas mikrobiologis pada minuman es coklat di Kota Semarang (Studi Di Kecamatan Tembalang Dan Kecamatan Pedurungan). Jurnal Kesehatan Masyarakat (e-Journal), 5(4), 342-349. https://ejournal3.undip.ac.id/index.php/jkm

Rahmayani, R. (2018). Hubungan pengetahuan, sikap dan tindakan hygiene sanitasi pedagang makanan jajanan di pinggir jalan. AcTion: Aceh Nutrition Journal, 3(2), 172178.

Riyanto, A., \& Abdillah, A. D. (2012). Faktor yang Memengaruhi Kandungan E. coli Makanan Jajanan SD di Wilayah Cimahi Selatan. Majalah Kedokteran Bandung, 44(2), 77-82. https://doi.org/10.15395/mkb.v44n2.127

Setiawati, Y., Purbowati, M. R., \& Ulfa, M. (2018). Pengaruh Perbedaan Waktu Pajan terhadap Jumlah Bakteri Salmonella sp. dan Shigella sp. pada Jajanan Pedagang Kaki 
Lima di Lingkungan Kampus 1 Universitas Muhammadiyah Purwokerto. HerbMedicine Journal, 1(1), 47-59. https://doi.org/10.30595/hmj.v1i1.2482

Sopandi, T., \& Wardah. (2014). Mikrobiologi Pangan . Malang: Andi

Supiandi, A. (2018). Usai Makan Tape Ketan Hitam, Puluhan Warga Keracunan. SindoNews.com. https://daerah.sindonews.com/berita/1270216/21/usai-makan-tapeketan-hitam-puluhan-warga-keracunan

Yasmin, G, \& Madanijah, S. (2010). Perilaku penjaja pangan jajanan anak sekolah terkait gizi dan keamanan pangan di Jakarta dan Sukabumi. Jurnal Gizi dan Pangan, 5(3), $148-157$.

Yunus, S. P., Umboh, J. M. ., \& Pinontoan, O. (2015). Hubungan personal higiene dan fasilitas sanitasi dengan kontaminasi escherichia coli pada makanan di rumah makan padang kota manado dan kota bitung. Biotechnology Advances, 5(2), 210-220. https://doi.org/10.1016/j.biotechadv.2010.08.010

Zein, U. (2004). Diare Akut Infeksius Pada Dewasa. Universitas Stuttgart. https://www.mendeley.com/catalogue/543c724d-2cc1-3291-bb4e-a0746daabdbc/ 